\title{
The Implementation of Scaffolding with The Breakout Room Feature On Zoom Meeting In Online Indonesian Mpk Learning
}

\author{
Kadek Wirahyuni. ${ }^{1}$, I Wayan Rasna ${ }^{2}$, I Nengah Martha ${ }^{3}$, Nyoman Sudiana ${ }^{4}$, I Nengah \\ Suandi ${ }^{5}$ \\ $\{\text { kadek.wirahyuni@undiksha.ac.id }\}^{1},\{\text { wayan.rasna@undiksha.ac.id }\}^{2}$, \\ $\{\text { nengah.martha@undiksha.ac.id }\}^{3},\{\text { nyoman.sudiana@undiksha.ac.id }\}^{4}$, \\ \{nengah.suandi@undiksha.ac.id $\}^{5}$
}

Universitas Pendidikan Ganesha, Singaraja, Bali ${ }^{12345}$

\begin{abstract}
During the Covid-19 pandemic, online learning becomes a solution to overcome educational problems, especially in teaching and learning. Therefore, this study aimed to determine the appropriate application of scaffolding and classroom management and related to the current online learning conditions. One of the video conferencing applications that are suitable for scaffolding is the Zoom application with its breaking room feature. The present study model was a classroom action research that consists of four stages, namely planning, implementing, observing, and reflecting. The samples of the study were the second-semester students consisting of 4 study groups. Each group consists of 35-40 students. It was proven by the mean value of the pre-test (pre-cycle) with the highest cycle (post-test) score of 38.55 for the pre-cycle, 67.58 for the stage cycle 1 , and 95.10 for the stage cycle 2. The students' response to the scaffolding implementation with breaking rooms feature of Zoom Meeting in online Indonesian MPK learning was $79.6 \%$ in agree category, and $20.4 \%$ in the strongly agree category.
\end{abstract}

Keywords: scaffolding, breakout room feature on Zoom Meeting, online Indonesian MPK learning

\section{Introduction}

The government has issued various policies as the first step in anticipating learning activities during this pandemic, including regulation of Circular Letter Number 15 the Year 2020 concerning A Guidelines for Organizing Learning from Home in an Emergency for the Spread of Covid-19 and Circular Letter of the Minister of Education and Culture Number 4 the Year 2020 concerning An Implementation of Education in the Period Emergency Coronavirus Disease (Covid-19). The General Directorate of Higher Education (Ditjen Dikti) has implemented various strategies in handling the Covid-19 pandemic emergency, which is expected to make the learning process more meaningful. The General Directorate of Higher Education collaborates with multiple parties to assist and facilitate the implementation of online learning. It is started from the collaboration with internet quota service providers. It is free to access online learning through online IPs registered at the General Directorate of 
Higher Education, platforms or media for conducting online lectures as well as training and capacity building for lecturers or the academic community to improve their ability in creating a material or continuous online learning content (General Directorate of Higher Education of Education Minister, Republic of Indonesia, 2020).

The educators and students can currently conduct teaching and learning activities from home through video conferencing, digital documents, and other online means. Thus, it is hoped that the teaching and learning activities will not affect the attendance levels of students and educators. Besides, learning objectives can be achieved, and learning materials can be fulfilled. In this industrial revolution era, educators cannot only use technology but also manage the class well. The management in this term means that educators can make the classroom atmosphere more interactive, fun, and innovative, integrated with technology. Educators must be able to use and integrate technology in learning. Suppose the teacher only explains the material and gives assignments without involving the adaptation of technology in it. In that case, it is feared that educators will not face the challenges of this 4.0 industrial revolution. The obstacles in online learning include the limitations of technology and the ability of educators to utilize technology (Kelly, 2015). The role of the teacher to form an agent of change is very necessary. Therefore, educators are needed in professionalism towards the $21^{\text {st }}$ century (Purnomo, 2020).

According to Komori (2014: 149), learning management must be developed through teaching principles that consider systematic learning strategies, which are conceptual but practical-realistic and flexible in terms of learning interactions, class management, utilization of learning resources, and learning evaluation. According to Prince (2014: 234), class management is an effort to organize, actualize, and supervise a program that has been planned so that the teaching and learning process runs effectively, systematically, and efficiently. According to Djabidi (2016: 39), class management is an activity that is conducted deliberately, including some movements such as planning, organizing, actualizing, and supervising the teaching and learning process in the classroom to create optimal activities. However, with today's online learning, educators who use video conferencing applications as face-to-face learning have difficulty managing classes. Face-to-face learning is mainly done by using zoom and google meet the application. Indeed, the use of zoom is the most widely used in virtual meetings. However, the drawback is the limited face-to-face time for unpaid users. Therefore, many educators shift to use google meet to conduct face-to-face learning virtually.

The implementation of video conferencing application in learning still face various obstacles, including the difficulty of managing classes and less optimal mentoring. Virtual face-to-face classroom management is complex, especially for educators who have limitations in the use of technology. It makes students unfocused and less enthusiastic about attending the class. In addition, less optimal mentoring makes students lack understanding of the presented material. Sometimes they are lazy to ask questions because of limited time and unconducive class conditions. At the Ganesha University of Education, the class with the most students per class is the Personality Course (MPK). The MPK class consists of 40-45 groups in which each class consists of 35-40 students. Therefore, the management of the type must be considered. One of the lessons included in the MPK is Indonesian Courses. The Indonesian course is a compulsory subject for the students in the first and second semesters. The questionnaire results showed that many students complained about their class management and less optimal mentoring. Therefore, it is necessary to have proper scaffolding and class management related to the current conditions of online learning. 
Scaffolding learning can be interpreted as providing structured learning support, which is conducted early to encourage students in independent learning. The provision of learning support is undertaken not continuously, but along with the increase in student ability, gradually educators must reduce and release students to learn independently. The implementation of scaffolding is the same as mentoring by educators in learning (Sudrajat, 2013). The performance of the structure in education considers the group's distribution to maximize mentoring by educators. In virtual face-to-face learning at university, the lecturers rarely divide students into groups. Several applications support the implementation of this group learning. One of them is zoom meeting. This video conferencing application is suitable for learning using scaffolding because it has a breaking room feature to divide students into groups. Students will join a virtual room in which only consists of a few students. This room will provide a good place for students to discuss, interact with each other, and have an opinion. Educators can join the created rooms so that mentoring can be more focused and intense.

Based on the explanation above, the researchers are interested in conducting a study on scaffolding with the breaking rooms feature of Zoom Meeting in Online Indonesian MPK learning which has never been done. The purpose of this study is to describe the implementation of scaffolding with the breaking rooms feature of Zoom Meeting in the Online Indonesian MPK learning, represent the success rate of scaffolding implementation with the breaking rooms of Zoom Meeting feature in Online Indonesian MPK learning, and find out students' responses toward the implementation of scaffolding with the breaking rooms feature of Zoom Meeting in MPK Indonesian online learning. The significance of the present study is to increase the students' insights about scaffolding learning by utilizing the breakout room feature. In addition, the practical relevance of the present study is to provide information about the implementation of scaffolding by using the breakout room feature in online learning.

\section{Research Method}

The objectives of the study were depended on the use of the method. In this classroom activity, the present study applied the John Elliot model (Purnamasari, 2020). The present study took place at the Ganesha University of Education in the second-semester students who took the Indonesian MPK course. The present study was conducted for six months for doing the observations, questionnaires, and interviews with the research sample, namely the secondsemester students consisting of four study groups. Each group consisted of 35-40 students.

The data were collected by conducting observation, questionnaires, and interviews. The obtained data were collected from the word and consultation with the students. The data from the implementation of scaffolding with the breakout room features were taken based on group discussion activities and learning evaluation tests conducted by all students at the end of the cycle. Data analysis was performed at each cycle. The data analysis process consisted of data during field research and collected data. The collected data were in the form of group discussion activities, observations, and interviews. 


\section{Results and Discussion}

The study results showed the implementation of scaffolding with the breakout rooms feature on Zoom Meeting in the Online Indonesian MPK learning, the success rate of scaffolding implementation with the breaking rooms feature on Zoom Meeting in the Online Indonesian MPK learning. Students' responses to scaffolding with the breaking rooms feature on Zoom Meeting in Online Indonesian MPK learning.

\section{Results}

The implementation of scaffolding with the Breaking Rooms feature on Zoom Meeting in the Online Indonesian MPK learning. This study consisted of two cycles repetitively covering cycle I and cycle II. In this study, each process included four stages as suggested by Suharsimi Arikunto, Suhardjono, and Supardi (2009: 16), as follows: (1) planning, (2) implementation, (3) observation, and (4) reflecting. The results of the reflection were used as the basis for determining improvement decisions in the next cycle.

The planning stages of the first and second cycles included some activities such as preliminary study and observation of the learning process on the Zoom Meeting room as well as students' learning outcomes, making learning designs based on scaffolding, making zoom meeting rooms for the learning process, compiling test questions to measure students' ability in mastering learning material, making answer keys to the evaluated questions, making observation sheets of students' activities in participating the Indonesian MPK learning activities, and conducting documentation. The implementation action discussed the material of the spelling system for 2 hours of lessons ( $2 \times 35$ minutes). In the learning process, it focused on students' understanding of the word form based on the rules of Indonesian. Initial, core, and closing activities were done at the implementation stage.

The initial activity began with the educator conducting the learning based on the design of the Zoom Meeting; the educator said greetings and invited all students to pray, the educator asked how the students were doing, the educator checked students' attendance, the educator delivered the material and learning objectives, the educator reviewed the last lesson, the educator gave instructions to prepare students' literature, and educators trained to teach media. The core activity consisted of three stages, namely the pre-reading stage, the reading stage, and the post-reading stage. The pre-reading stage begun with the educator presenting the article in learning. Then, the educator asked students to look at the displayed themes. The educator introduced a text for writing analysis. Next, the educator activated the breaking room feature on Zoom and divided the students into several groups. The reading stage began with the students reading the displayed text by the educator. The educator guided the students to do reading activities, and the students checked the predictions by looking for the truth and mistakes of the forecast. At the post-reading stage, the educator allowed students to discuss their findings with their teammates in the breakout room. The educator accompanied them, oversaw the course of the discussion, and rectified the wrong understandings in the debate. The students concluded the discussion session, and the educator turned off the breakout room feature. Then, the educator asked again about the text that students had read. Then, the students presented the results of their analysis.

The closing activity began with the educator providing the conclusions from the learning activities carried out. The educator closed the learning activities and reminded students to learn the following material. The educator closed the lesson by praying and saying goodbye. The observation was conducted to observe the students' behavior and attitudes following the 
Indonesian MPK course by applying scaffolding-based learning and utilizing the breakout room feature on Zoom Meeting. This stage was done in the learning process or at the action stage. The observation was directed at the points based on the set indicator. The results of observation of students' attitudes and behavior during the lesson were conducted as material for consideration in reflecting. From the data of students' words during learning, it could be seen that: a) the involvement of students in taking lessons had begun to increase. Students were already active in learning activities. Students had already experienced learning based on scaffolding and breakout room features used in learning activities and b) increasing students' enthusiasm in taking online lessons.

The final stage was reflection. Reflection was an evaluation stage of the planning and implementation of learning that had been implemented. Reflection was done to determine the advantages and disadvantages of planning and executing the study. During the learning process, several obstacles were found, namely: 1) the geographic location of students was not the same so that it was constrained by the network, 2) some students still did not understand the use of zoom media, 3) less conducive learning caused by the students' enthusiasm in discussion sessions, and 4) some students were still late to follow learning.
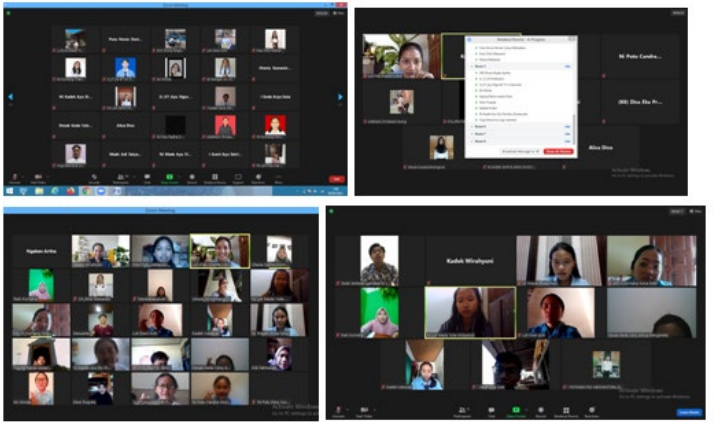

Figure 01 . The activities of the first cycle

The final stage in cycle II was reflection. Based on the results of observations, there was a success in the learning process. Namely, students could participate in learning activities well comparing to the previous cycle. Almost all students were actively involved in improving the learning outcomes of the Indonesian MPK learning, especially on spelling material, and had reached the minimum criteria of mastery learning. The observations in cycle II were good, so there is no need for the next cycle.
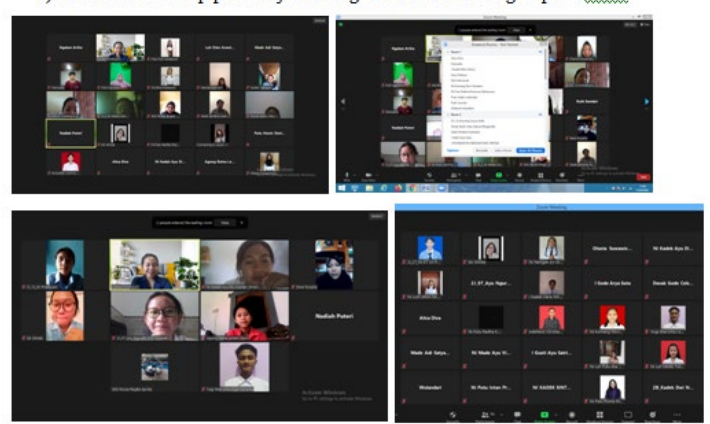

Figure 02 . The activities of the second cycle

The success rate of scaffolding with the Breaking Rooms feature on Zoom Meeting in Online Indonesian MPK learning was very good. The mean score of the pre-test (pre-cycle) 
was proven by the highest cycle score (post-test). The obtained average score was 38.55 for the pre-cycle, 67.58 for cycle 1 , and 95.10 for cycle 2 . The effectiveness test of the Scaffolding Application with the Breaking Rooms Features on Zoom Meeting in the online Indonesian MPK learning was done by giving questions in the form of pre-test questions and the highest post-test questions to determine the comparison of the obtained scores by students before and after implementing the application of scaffolding with the breaking room feature on Zoom Meeting in MPK Indonesian online learning. To see the changes, the result of students' tests could be presented in the following table.

(1) Table of the Result of Online Indonesian MPK learning Test with the application of scaffolding and breakout room on Zoom Meeting

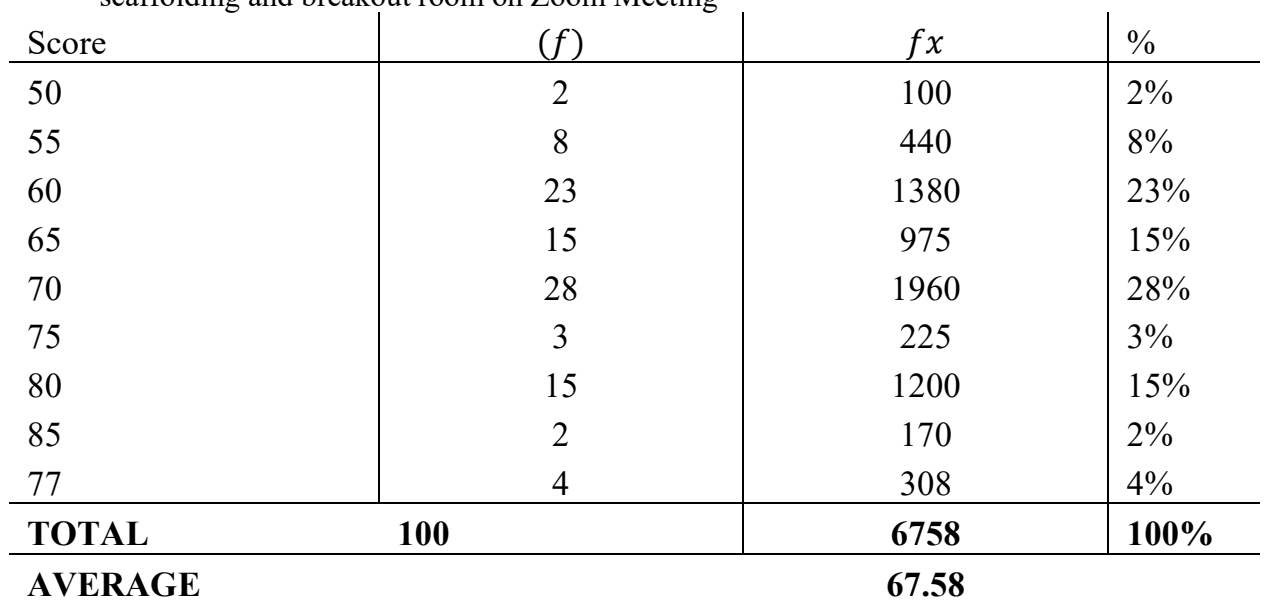

(2) Table of the Result of Online Indonesian MPK learning Test with the application of scaffolding and breakout room on Zoom Meeting

\begin{tabular}{l|c|c|l} 
Score & $(f)$ & $f x$ & $\%$ \\
\hline 85 & 9 & 765 & $9 \%$ \\
90 & 20 & 1800 & $20 \%$ \\
95 & 31 & 2945 & $31 \%$ \\
100 & 40 & 4000 & $40 \%$ \\
\hline TOTAL & $\mathbf{1 0 0}$ & $\mathbf{9 5 1 0}$ & $\mathbf{1 0 0 \%}$ \\
\hline
\end{tabular}

AVERAGE

95.1

The results of students' responses were shown in the following diagram.

After implementing the scaffolding with the breaking room features on zoom meeting in the Online Indonesian MPK learning involving 100 students as respondents, based on questionnaires and interviews given to students as a population, the following responses were obtained.

Diagram 01. Students' responses to network constraints in Online Indonesian MPK learning 


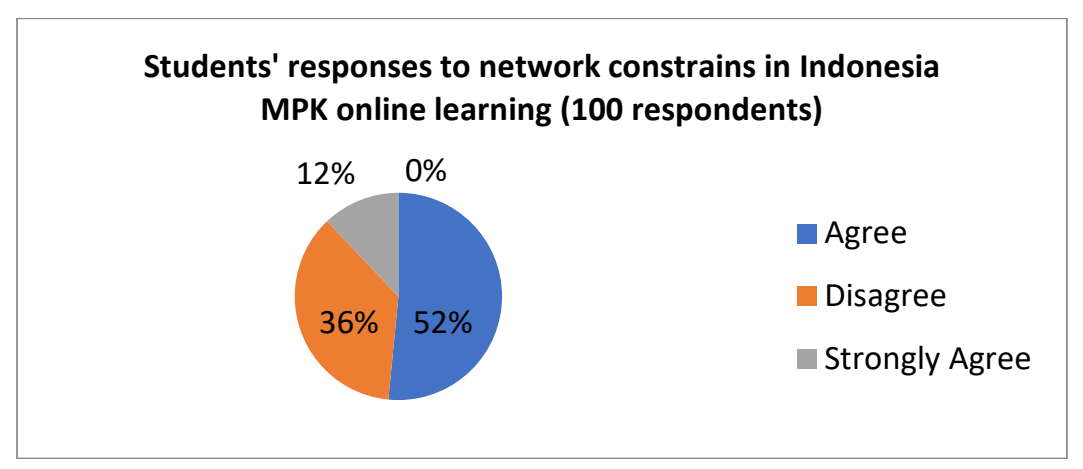

The statements related to network constraints in Online Indonesian MPK learning experienced by students stated that $46.7 \%$ in agree category, $40 \%$ in disagree category, and $13.3 \%$ in the strongly agree category. This shows that the reality in the field, network constraints often interfere with online learning, especially in Indonesian language MPK learning. Interviews with students randomly stated that the geographical location and electronic means used caused difficulties in participating in online learning activities.

Diagram 02. Students' focus in participating the Indonesian MPK learning before using Breakout room on Zoom Meeting

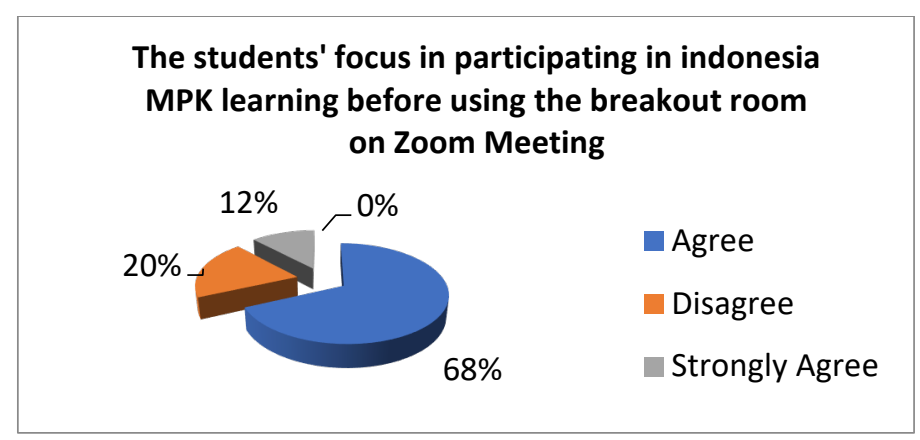

The lack of students' focus in online learning stated that $68.9 \%$ in the agreed-on category, $20 \%$ in disagree category, and $12.1 \%$ in the strongly agree category. It showed that the students did not focus on online learning before using the breakout room on Zoom Meeting. The interviews with random students stated that the sizeable virtual meeting room online and contained many participants caused the students' focus to decrease.

Diagram 03. The need for mentoring discussion activities (scaffolding) during the Online Indonesian MPK learning 


\section{Students' response to application of scaffolding in Indonesian MPK online learning}

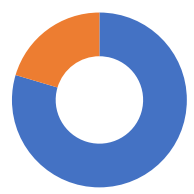

- Agree

Strongly Agree

The statement regarding scaffolding in Indonesian MPK learning stated that $79.6 \%$ in agree category and $20.4 \%$ in the strongly agree category. It showed that the students needed a frame in online education, especially Indonesian MPK. The application of scaffolding could increase students' motivation and creativity because of the external encouragement provided by educators. Students had a better understanding of the material in the discussions assisted by mentoring.

Diagram 04. The effectiveness of breakout rooms in mentoring discussions (scaffolding)

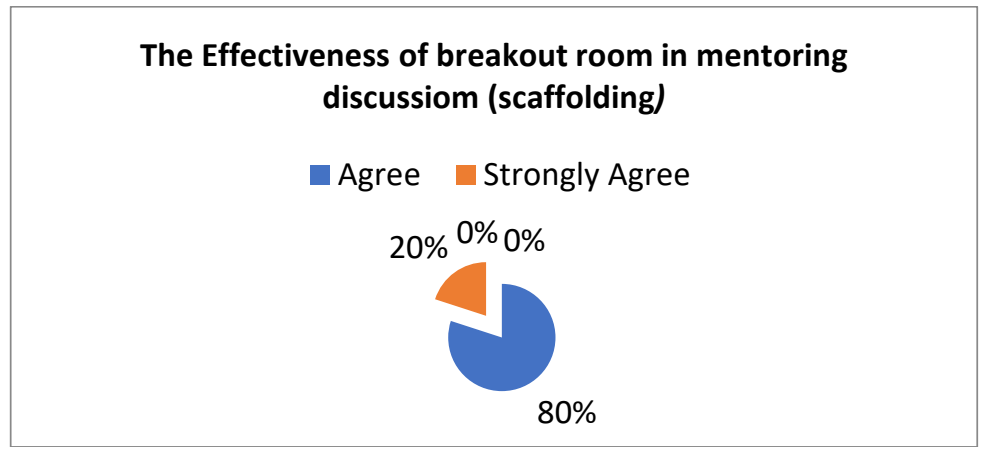

The statement related to giving the opportunity in small group discussions with the breaking room feature in the Indonesian MPK learning stated that $80 \%$ agree on category and $20 \%$ strongly agree on the type. It showed that the students in actual situations needed to discuss with small groups in online learning, especially Indonesian MPK. With the distribution of virtual rooms to small groups during education, students would be more active in expressing their opinions. Exchanging opinions was critical in learning because it could improve students' critical thinking and speaking skills.

\section{Discussion}

The pre-cycle or pre-test scores of students were initially low, but now it tended to increase slowly. The activities of students participating in the learning process also increased from being passive to being active. Students also began to actively express their opinions so that the quality of student learning outcomes was very satisfying. Based on cycles I and II data, scaffolding with the breaking rooms features on Zoom Meeting in Online Indonesian MPK learning improved student's learning outcomes. The advantages of scaffolding in Indonesian MPK were as follows: increasing students' motivation and interest in learning, 
turning on online learning activities, helping students to focus more on achieving goals, reducing student laziness, and controlling student activities. The support for students in completing the learning process could be in the form of student activeness in the learning process, learning strategies, diversity of learning models, experiential guidance framings, learning facilities, and the learning climate of students.

Based on the data collection analysis, it showed that there was an enhancement. The mean score of pre-cycle was $70 \%$, cycle 1 was $79.5 \%$, and cycle II was $95.1 \%$.

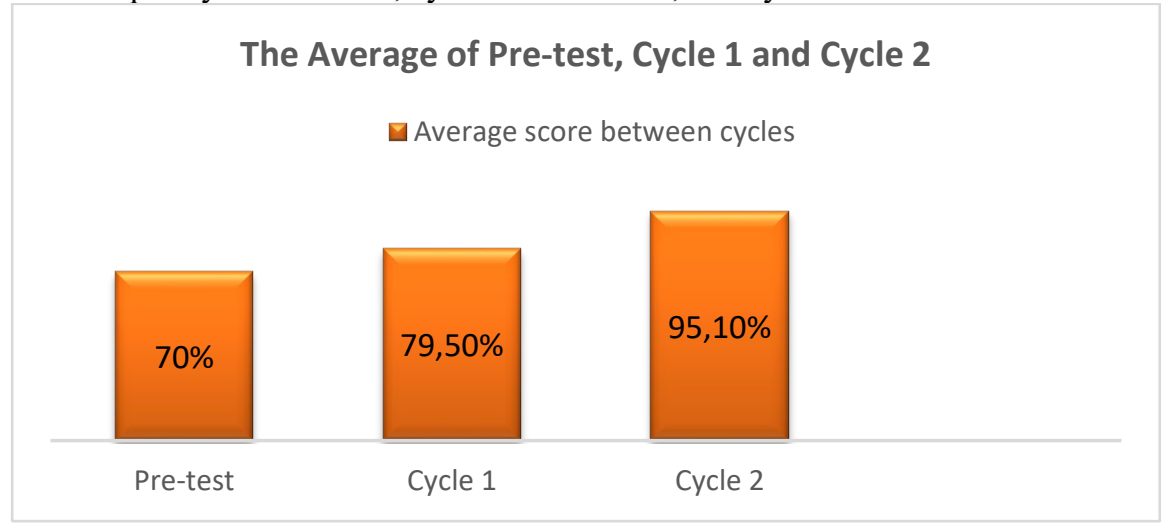

Figure 03.Chart of Pre-test, Cycle 1, and Cycle 2

Based on the chart above, it could be concluded that the pre-cycle or pre-test scores of students, which were initially low, tended to increase slowly. The students' activities in participating in the learning process also increased from being passive to being active. Students also began to actively express their opinions so that the quality of student learning outcomes was very satisfying. Based on cycles I and II data, scaffolding with the breaking rooms features on Zoom Meeting in Online Indonesian MPK learning improved student's learning outcomes. The advantages of framing in Indonesian MPK were increasing students' motivation and interest in learning, turning on online learning activities, helping students to more focus on achieving goals, reducing students' laziness, and controlling students' activities. The support for students in completing the learning process could be in the form of students' activeness in the learning process, learning strategies, diversity of learning models, experiential guidance from learners, learning facilities, and the learning climate of students.

The educators were not required to have all knowledge, but they should have sufficient knowledge based on what focus more provide learning support to the students, where to get it, and how to interpret it. The educators were expected to act based on deep thinking, work independently and collaboratively with one another, and be ready to contribute a critical consideration. They were expected to become people with broad knowledge and deep understanding. The breaking room feature on zoom in the learning process helped the educator's group of students and provided motivation based on the scaffolding principle. The educators had full authority in overseeing the course of the discussion, and the students had the opportunity to express their opinions. The silent students had an excellent opportunity to deliver their thought in a smaller space. The use of the breaking room feature on zoom gave the students and educators a benefit in undergoing the learning process and getting maximum results. Based on the development of the tests, the student also showed good responses in the implementation of scaffolding activities with the breaking room feature on zoom in the Online 
Indonesian MPK learning. This positive response further confirmed a need for updates to the online learning process to increase the students' enthusiasm for learning.

\section{Conclusions}

Based on the results of data analysis, it can be concluded as follows: The application of scaffolding with the breaking rooms feature on Zoom Meeting in Online Indonesian MPK learning undergoes two cycles of action using the John Elliot model, which consists of a planning stage consisting of planning things that will be prepared in the learning process, an implementation which is the core part of the activation process for students, observation consisting of re-observing patterns before and after the implementation of the action, and reflection consisting of the evaluation results of the actions both good results and constraints. The success rate of scaffolding implementation with the Breaking Rooms features on Zoom Meeting in Online Indonesian MPK learning is excellent. It can be seen from a mean score of pre-test (pre-cycle) with the highest cycle score (post-test). The obtained average score was 38.55 for the pre-cycle, 67.58 for cycle 1, and 95.10 for cycle 2. Students' responses to the effectiveness of the application of scaffolding with the Breaking Rooms features on Zoom Meeting in Online Indonesian MPK learning is $79.6 \%$ in agree category and $20.4 \%$ in strongly agree on category. It shows that students agree with the breaking room feature on the zoom because it provides discussion space and intense external motivation from educators.

There are some suggestions for some parties. For educators as teaching staff, it is expected that the educators use scaffolding to strengthen the learning, especially Indonesian MPK, to make students have creative ideas in education. Educators must take advantage of the context around students by collecting data and motivating students to maximize their potential. In addition, educators must take advantage of the various features available in learning media, such as the Zoom Meeting. By utilizing the breaking room feature on Zoom Meeting to the fullest, educators can create a fun online learning atmosphere for students and be well controlled through mentoring. Students should also follow the directions or instructions of educators to achieve learning success based on the learning objectives. It is hoped that other researchers can improve the application of scaffolding with the breaking rooms feature on Zoom Meeting in Online Indonesian MPK learning. In addition, the result of the study can be used as a reference, guideline, and comparison material to add to the following research.

\section{References}

[1] Agustino, L. 2020. Analisis Kebijakan Penanganan Wabah Covid-19: Pengalaman Indonesia. Jurnal Borneo Administrator. 2020; 16(2); 253-270.

[2] Aurélie, M., Fabre, A., Minodier, P., Boutin, A., Vanel, N., Bosdure, E., \& Fournier, P.-E. COVID-19 Virus And Children: What Do We Know? Archives De Pédiatrie. 2020; https://doi.org/10.1016/j.arcped.2020.03.001. Diunduh pada 9 Februari 2021.

[3] Bransford, J., Brown, A., \& Cocking, R. How People Learn. Brain, Mind, Experience, and School. Washington DC: National Academy Press. 2000.

[4] Brown, D. H. Prinsip Pembelajaran dan Pengajaran Bahasa, Edisi Kelima (5th ed.; N. C. and Avianto \& Yusi, eds.). Jakarta: Kedutaan Besar Amerika Serikat. 2007. 
[5] Chandler, K. Using Breakout Rooms in Synchronous Online Tutorials. Journal of Perspectives in Applied Academic Practice, 2016; 4(3). https://doi.org/10.14297/jpaap.v4i3.216.

[6] Cole, S., Haynes, M., Lown, J., Ulanowsky, C., \& Salmon, G. Effective Group Work. Milton Keynes: The Open University. 1999.

[7] Dewi, Wahyu Aji Fatma. Dampak Covid-19 Terhadap Implementasi Pembelajaran Daring Di Sekolah Dasar. Edukatif: Jurnal IlmuPendidikan. 2020: Volume 2 Nomor 1, hlm 55-61.

[8] Djabidi, F. Manajemen Pengelolaan Kelas Upaya Peningkatan Strategi dan Kualitas dalam Pembelajaran. Malang: Madani. 2016.

[9] Erduran, S. Science Education in the Era of a Pandemic. Science \& Education, 29(2), 233- 235. 2021: https://doi.org/10.1007/s11191-020- 00122-w.

[10] Halijah, N. Pentingnya Kolaborasi Guru dan Orangtua Siswa dalam Pembelajaran Daring. Koran Metro Riau (Issue 20). Edisi Jumat, 14 Agustus 2020.

[11] Hall, J. K. Methods for Teaching Foreign Languages. New Jersey: Merrill Prentice-Hall. 2001.

[12] Handarini, Oktafia Ika. Pembelajaran Daring Sebagai Upaya Study From Home (SFH) Selama Pandemi Covid 19. Jurnal Pendidikan Administrasi Perkantoran (JPAP). 2020: Volume 8, Nomor 3, 2020, hlm. 496-503.

[13] Harbani, dkk. A Web-Cloud Video Conferencing Platform To Facilitate Online English Language Teaching. Prosiding Seminar Nasional Penelitian \& Pengabdian Kepada Masyarakat. 2020.

[14] Hasanah, dkk. Analisis Aktivitas Belajar Daring Mahasiswa Pada Pandemi COVID-19. Jurnal Pendidikan. 2020: Volume 1 No.1.

[15] Hasibuan, M.S dkk. E-Learning: Implementasi, Strategi dan Inovasinya. Medan: Yayasan Kita Menulis. 2019.

[16] Hasmidyani. Dwi dan Firmansyah. Pendekatan Scaffolding Sebagai Upaya Meningkatkan Aktivitas Dan Hasil Belajar Mahasiswa. Jurnal Profit. 2016. Vol 3, No 1 Mei (2016), hlm. 87-100

[17] Kelly, D. Overcoming Barriers To Classroom Technology Integration. Journal Educational Technology. 2015: 55,p. 40-43.

[18] Kemendikbud. Pedoman Penyelenggaraan Pembelajaran Pada Tahun Ajaran Dan Tahun Akademik Baru Pada Masa Pandemi Covid-19. 2020: https://dikti.kemdikbud.go.id. Diunduh pada 10 Februari 2021.

[19] Kompri. Manajemen Sekolah Teori dan Praktek. Bandung: Alfabeta. 2014.

[20] Kusniyah \& Hakim,L. Efektifitas Pembelajaran Berbasis Daring: Sebuah Bukti pada Pembelajaran Bahasa Inggris. Jurnal Pemikiran dan Penelitian Pendidikan. 2019: Vol. 17 No.1.

[21] Layla, Muslena. Analisis Kepuasan Penggunaan Aplikasi Zoom Dalam Mengikuti Webinar Selama Pandemi Covid-19 Menggunakan Webqual 4.0 (Studi Kasus: Dosen Stain Sultan Abdurrahman Kepri). Tanjak: Journal of Education and Teaching. 2020: Volume 1 Nomor 2, 2020, hlm. 169-177.

[22] Lipscomb et al. Scaffolding. Jakarta: Gaung Persada. 2005.

[23] Mamin, Ratnawati. Penerapan MetodePembelajaran Scaffolding Pada Pokok Bahasan Sistem Periodik Unsur. Jurnal Chemica. 2008: Vol 2 hlm.55-60.

[24] Mardiyah, R. A. Dampak Pandemi Covid-19 Terhadap Peningkatan Angka Pengangguran Di Indonesia. Jurnal Ekonomi Pembangunan. 2020: Vol.25(1).

[25] Martins, M. de L. How to Effectively Integrate Technology in the Foreign Language Classroom for Learning and Collaboration. Procedia. Social and Behavioral Sciences. 2015: Vol. 174, Halm. 77 84.

[26] Misno, Abdurrahman. Covid-19: Wabah, Fitnah, dan Hikmah. Bogor: Pustaka Amma Alami. 2020.

[27] Muhammad, Adnan, et al. Online Learning Amid the COVID-19 Pandemic: Students Perspectives. National University of Sciences \& Technology, Pakistan. 2020: Volume 2, Issue 1.

[28] Muhammad, Hamid. Kemendikbud Sebut PJJ Tak Sama dengan PembelajaranDaring dan Luring. 2020: https://www.jawapos.com/nasio nal/pendidikan/17/06/2020/. Diunduh pada 12 Februari 2021. 
[29] Nasir, dkk. Memaksimalkan Fitur "Breaking Rooms" Zoom Meeting pada Pendidikan Anak Usia Dini di Masa Pandemi Covid-19. Jurnal Obsesi : Jurnal Pendidikan Anak Usia Dini. 2021: Volume 5 Issue 1 (2021) Pages 611-624.

[30] Nugraha, S. A., Sudiatmi, T., \& Suswandari, M. Studi Pengaruh Daring Learning terhadap Hasil Belajar Matematika Kelas IV. Jurnal Inovasi Penelitian. 2020: 1(3), 265-276.

[31] Priansa, Donni Juni. 2014. Manajemen Peserta Didik dan Model Pembelajaran. Bandung: Alfabeta. 2014.

[32] Priyatni, E.T. Peningkatan Kompetensi Menulis Paragraf dengan Teknik Scaffolding. Makalah disajikan dalam Semiar Bahasa dan Seni, Malang. 2008.

[33] Purba, H.H. Diagram Fishbone dari Ishikawa. 2008: http://hardipurba.com/2008/09/25/diagram-fishbone-dari- ishikawa.html. Diunduh pada 7 Februari 2021.

[34] Purnamasari, Annisa. Upaya Meningkatan Kemampuan Berpikir Kritis Siswa Dengan Model Problem Based Learning Dengan Platform Zoom FiturBreakout Room Di Kelas VII-A SMP Labschool Cibubur. 2020: https://portal.labschoolcibubur.sch.id/smp/upaya-meningkatankemampuan-berpikir-kritis-siswa-dengan-model-problem-based-learning-dengan-platform-zoomfitur-breakout-room-di-kelas-vii-a- smp-labschool-cibubur/. Diunduh pada tanggal 9 Februari 2021.

[35] Purnomo, Halim, dkk. Pengelolaan Kelas Belajar di Era 4.0. Jurnal ElementariaEdukasia, 2020: Vol.3, No.1.

[36] Rahayu, Puji, dkk. Scaffolding dalam Pembelajaran Mata Kuliah Struktur Aljabar. Jurnal Ilmiah Pendidikan Matematika. 2020: Vol. 5, No. 1.

[37] Riyana, C. Produksi Bahan Pembelajaran Berbasis Online. Universitas Terbuka. 2019.

[38] Sahu, P. Closure of Universities Due to Coronavirus Disease 2019 (COVID- 19): Impact on Education and Mental Health of Students and Academic Staff. Journal Cureus. 2019: (April). https://doi.org/10.7759/cureus.7541.

[39] Santrock, John W. Psikologi Pendidikan, Edisi Kedua. Jakarta: Kencana. 2008.

[40] Sapitri, E. Paud Dikdasmen Sebut Ada 4 Kebijakan Pembelajaran Selama Pandemi COVID-19. 2020: https://www.Pikiran-Rakyat.Com/ website: https://www.pikiranrakyat.com/nasional/pr- 01375412/paud-dikdasmen-sebutada-4-kebijakan-pembelajaran- selamapandemi-covid-19?page=all. Diunduh pada 10 Februari 2021.

[41] Sobron, A.N.,dkk. Persepsi Siswa Dalam Studi Pengaruh Daring Learning Terhadap Minat Belajar IPA. SCAFFOLDING: Jurnal Pendidikan Islam dan Multikulturalisme. 2019: Vol. 1, No. 2, Desember 2019.

[42] Sofyana \& Abdul. Pembelajaran Daring Kombinasi Berbasis Whatsapp Pada Kelas Karyawan Prodi Teknik Informatika Universitas PGRI Madiun. Jurnal Nasional Pendidikan Teknik Informatika. 2019: Volume 8 Nomor 1, Halm. 81-86.

[43] Sudrajat, Akhmad. Pembelajaran Scaffolding untuk Kesuksesan Belajar Siswa. 2013: https://akhmadsudrajat/2013/12/02/pembelajaran-scaffolding-untuk-kesuksesan-belajar-siswa/. Diunduh pada 9 Februari 2021.

[44] Sugiyono. Metode Penelitian Pendidikan, Pendekatan Kuantitatif, Kualitatif, dan R \& D. Bandung: Alfabeta. 2013.

[45] Sugihartono, dkk. Psikologi Pendidikan. Yogyakarta: UNY Press. Tague, N. R. 2005. The Quality Toolbox. Milwaukee: ASQ Quality Press. 2007.

[46] World Bank. Guidance Note On Education Systems' Response To COVID19 How Does COVID 19 Impact Education. 2020: https://www.cdc.gov/coronavirus/2019ncov/downloads/considerations-for-school-closure.pdf. Diunduh pada10 Februari 2021.

[47] Zamahzari, Gamal Kusuma. Implementasi Scaffolding dalam Pembelajaran BIPA di Kelas Pemula. Jurnal Pendidikan: Teori, Penelitian, dan Pengembangan. 2019: Volume 4, Nomor 1, Januari, 2019, hlm.68-7. 